\title{
Mechanical Behavior of Asphalt Mixtures Containing Silica Gels as Warm
} Additives

\author{
Elsa Sanchez-Alonso ${ }^{\text {a*; }}$ Angel Vega-Zamanillo ${ }^{\text {b; }}$ Miguel Angel Calzada-Perez ${ }^{\text {c }}$; \\ Daniel Castro-Fresno ${ }^{\mathrm{d}}$ \\ ${ }^{a}$ Department of Civil Engineering, Universidad de La Frontera, Francisco Salazar 01145, 4811230 \\ Teтисо, Chile \\ ${ }^{b}$ Department of Transport, Project and Process Technology, School of Civil Engineering \\ (E.T.S.I.C.C.P.), University of Cantabria (UC), Avenida de los Castros s/n, 39005 Santander, \\ Cantabria,Spain.vegaa@unican.es. \\ ${ }^{c}$ Department of Transport, Project and Process Technology, School of Civil Engineering \\ (E.T.S.I.C.C.P.), University of Cantabria (UC), Avenida de los Castros s/n, 39005 Santander, \\ Cantabria, Spain.miguel.calzada@unican.es. \\ ${ }^{d}$ Department of Transport, Project and Process Technology, School of Civil Engineering \\ (E.T.S.I.C.C.P.), University of Cantabria (UC), Avenida de los Castros s/n, 39005 Santander, \\ Cantabria, Spain.castrod@unican.
}

\begin{abstract}
This paper presents the results of a study of some compounds capable of absorbing water into their structure (silica gel), as potential foaming binders. Asphalt mixtures were manufactured at different manufacturing and compaction temperatures, using four different silica gels. Static and dynamic tests were carried out to determine their behavior in asphalt mixtures. The results were compared with those obtained using hot-mix asphalt and warmmix asphalt manufactured with zeolite. The lab results showed a similar behavior of asphalt mixtures containing either silica gel or zeolite.
\end{abstract}

Keywords: silica gel; zeolite; additives; warm asphalt mixtures; rutting; fatigue

\footnotetext{
* Corresponding author Tel.: (+56) 452325696

E-mail addresses: elsa.sanchez@ufrontera.cl
} 


\section{Introduction}

Different technologies are used to reduce energy consumption during manufacture and compaction of asphalt mixtures, some based on the use of additives and others on the use of water. These water technologies can be used with a system of nozzles (e.g. Double Barrel $\left.{ }^{\circledR}\right)$, wet aggregates during the production process (e.g. WAM Foam ${ }^{\circledR}$ or LEA $\left.{ }^{\circledR}\right)$ in order to produce foaming binders or additives can be used within the mix to achieve a foam of bitumen (e.g. zeolites) [1]. These methods achieve a reduction of the binder viscosity, coating the aggregates at lower temperatures.

Zeolites are aluminosilicate compounds, and depending on the type of zeolite have a pore size from $3 \AA$ to $8 \AA$. Due to this porous structure, they have an ion exchange capacity and can contain different molecules [2]. The zeolites used in the asphalt industry contain crystallisation water in a percentage close to $20 \%$ by weight. Adding zeolites during the manufacture of asphalt mixtures, their water content is released foaming the bitumen, obtaining an improvement in the coating of aggregates and the manageability of the asphalt mixture at lower temperatures [3].

Several authors have studied the behavior of warm-mix asphalts (WMA) with zeolites (Aspha-Min ${ }^{\circledR}$ ), finding that their use improved the mixture compaction, the resilient modulus was not affected and did not increase the susceptibility to rutting of asphalt mixtures [4]. Akisetty et al. [5] concluded that it is possible to reduce the compaction temperatures in crumb rubber-modified asphalt mixtures using additives, among them the zeolite Aspha-Min ${ }^{\circledR}$, achieving a suitable percentage of air voids. Tao and Mallick [6] showed that Reclaimed Asphalt Pavement (RAP) content could be increased to 100\% through the use of the zeolite Advera ${ }^{\circledR W M A}$, obtaining an increase in stiffness of the asphalt mixture at temperatures below $80^{\circ} \mathrm{C}$ and enhancing the indirect tensile strength. Sengoz et al. [7] determined the stability in storage and the temperature of mixing and 
compaction, as well as the rheological properties to check the performance of asphalt mixtures manufactured with zeolite, an organic additive and a chemical additive. According to the results obtained, the mixing and compaction temperatures are reduced between 6$13^{\circ} \mathrm{C}$ and $6-10^{\circ} \mathrm{C}$, respectively; depending on the type of additives used. The optimal additive content is $3 \% \mathrm{w} / \mathrm{b}$ for the organic and chemical additives and between $5-6 \% \mathrm{w} / \mathrm{b}$ for zeolites for use in heavy traffic and high temperature conditions.

$\mathrm{Xu}$ et al. [8] made a review about the moisture damage behavior of WMA evaluating the effects of different types of technologies, type of aggregate, type of binder and use of additives as influential factors in resistance to moisture damage of WMA. Among the conclusions, the authors indicated that in foaming technologies it is crucial to verify the optimum percentage of additive, and optimize the mixing temperature. Both factors will significantly influence in achieving a better coating of aggregates and decrease the water content trapped in the asphalt mixture, influential factors in the resistance to the moisture damage.

De Visscher et al. [9] studied the mechanical properties of asphalt mixtures using different zeolites. The results indicated that reducing the compaction temperature below $120^{\circ} \mathrm{C}$, the use of zeolites had a negative effect on the compactability and water sensitivity; but reducing the manufacture temperature $30^{\circ} \mathrm{C}$ did not lead to a negative effect on the rutting resistance compared to a reference mixture manufactured at $150^{\circ} \mathrm{C}$. Woszuk and Franus [10] evaluated the mechanical properties of synthetic and natural zeolites, which have $28 \%$ and $17 \%$ water in their structure, respectively. Three compaction temperatures in the design of the mixtures $\left(145^{\circ} \mathrm{C}, 130^{\circ} \mathrm{C}\right.$ and $\left.115^{\circ} \mathrm{C}\right)$ were used; obtaining an optimum content of natural zeolite of $1 \% \mathrm{w} / \mathrm{m}$ and $0.5 \% \mathrm{w} / \mathrm{m}$ for the synthetic one. The results of water sensitivity and permanent deformations showed a good performance with both zeolites according to Polish standards. 
Hossain et al. [11] demonstrated that the addition of $6 \%$ by weight of bitumen of the zeolite Advera ${ }^{\circledR}$ WMA did not change the PG grade of the original binder. They also aged the bitumen using the rolling thin film oven test (RTFOT) at a temperature of $150^{\circ} \mathrm{C}$ and tested with dynamic shear rheometer (DSR), reducing the rutting resistance of the modified binder, although the authors indicated that it could be due to the reduction of manufacture temperature rather than the use of the additive. Topal et al. [12] evaluated the Marshall stability, stiffness modulus and indirect tensile fatigue of asphalt mixtures manufactured with natural and synthetic zeolites. According to the data shown by the authors, there would be a slight decrease in the amount of binder needed with respect to the conventional hot asphalt mixture, which it would mean an initial cost savings. The use of both zeolites increased the stiffness of the asphalt mixture. However, the results of fatigue resistance and permanent deformation were slightly better with the synthetic zeolite.

$\mathrm{Wu}$ and $\mathrm{Li}$ [13] studied the curing time for WMA manufactured with synthetic zeolite (Advera ${ }^{\circledR W M A}$ ), and tested their behavior in dynamic modulus, rutting, resistance to moisture damage and fatigue behavior. The results showed that the WMA properties improved with the curing time, probably due to the elimination of water contained in the asphalt mixture, unlike hot asphalt mixture which has not shown difference in its performance after the curing time evaluated.

Goh and You [14] studied dynamic moduli and four-point beam fatigue of asphalt mixtures with wax (Sasobit®) and zeolite (Advera®WMA) additives, manufactured and compacted at different temperatures. The dynamic moduli of WMA were lower than hot mix asphalt (HMA) at most temperatures and frequencies tested and, the greater the compaction temperature of WMA, the greater the modulus value. The mixtures with zeolites were less stiff than wax mixtures. WMA showed similar or higher fatigue life than HMA, except when they were manufactured and compacted at $130^{\circ} \mathrm{C}$. 
Silica gels are amorphous silicon dioxides, very porous, with high surface area [15]. Due to their porosity and surface area, the silica gels could be used to separate and adsorb molecules, in high performance liquid chromatography, in membrane technology and molecular engineering, in chemical-mechanical surface treatment, among other [16]. The pore size is usually between $5 \AA$ and $300 \AA$, depending on the synthesis process used [16]. The adsorption capacity of silica gel is based on physical adsorption, that is, the molecules are bound by Van der Waals forces at the surface [17]. The regeneration of silica gels, releasing molecules adsorbed, could be carried out by three methods: increasing the temperature, lowering the molar concentration of the adsorbate or lowering of the system pressure [17]. The regeneration at high temperatures can be carried out by heating up to $800^{\circ} \mathrm{C}$ depending on the absorbed components, being in the case of water molecules above $100^{\circ} \mathrm{C}[18]$

Due to the water absorption-desorption capacity of the silica gels, and the release of water at the manufacture temperature of WMA without affecting the structure of the silica gel whose melting point is higher than $1600^{\circ} \mathrm{C}$ [19]; these materials may be an alternative to the use of synthetic zeolites for the manufacture of WMA.

Therefore, this paper evaluate if silica gels may be used as alternative additives in WMA. The foamed asphalt mixture has been simulated using several silica gels, comparing their results with WMA manufactured with zeolite. The ease of compaction and static and dynamic mechanical properties have been studied in asphalt mixtures modified with some additives (zeolite and silica gels) at different manufacturing and compaction temperatures, also comparing their results with HMA. 


\section{Experimental Research}

This paper studied the mechanical properties of asphalt mixtures containing silica gels, manufactured at different temperatures, to determine whether they may be used as foamed additives.

\subsection{Materials used and Mix design}

In this paper, an aggregate gradation with maximum aggregate size of $16 \mathrm{~mm}$ and for use in the surface layer (AC16Surf) was chosen. The AC16Surf aggregate gradation was adjusted to the centre of the grading envelope (Table 1), using ophite coarse aggregates and limestone sand. The aggregates' properties are described in Table 2.

The asphalt mixtures were manufactured with a B-50/70 penetration bitumen (Table 3), using the optimum binder content of $4.5 \%$ weight of $\operatorname{mix}(\mathrm{w} / \mathrm{m})$ obtained with the Marshall procedure [20] and the analysis of air void content [21].

In this research, five additives (F1-F5) were studied, whose characteristics are described in Table 4.

F1 is usually used in WMA and $0.3 \% \mathrm{w} / \mathrm{m}$ was added in as recommended by the manufacturer. The amount of each silica gel additive used (F2-F5) was calculated to add the same amount of water as synthetic zeolite to simulate the foaming effect. For this, the water absorption was calculated in situ as follows: an amount of each silica gel was weighted in a vessel and then distilled water was added until no more water was absorbed, and the silica gel particles were not clustered. Thus, the amount of each silica gel to simulate the foaming process was: $0.06 \% \mathrm{w} / \mathrm{m}$ for $\mathrm{F} 2 ; 0.02 \% \mathrm{w} / \mathrm{m}$ for $\mathrm{F} 3$ and $\mathrm{F} 5$, and $0.10 \% \mathrm{w} / \mathrm{m}$ for $\mathrm{F} 4$. The five additives were added into the asphalt mixture (it is necessary to hydrate the silica gels before adding them) at the same time as the bitumen to achieve the foaming effect. 
The asphalt mixtures were manufactured and compacted at three temperatures: $160^{\circ} \mathrm{C}$, typical temperature of $\mathrm{HMA} ; 140^{\circ} \mathrm{C}$ and $120^{\circ} \mathrm{C}$, temperatures of WMA. To maintain the selected manufacture temperature, a mixer with control of temperature was used. This mixer has a mixing bowl with 201 of capacity, thermally insulated.

\subsection{Test methods}

\subsubsection{Adsorption isotherms}

The water adsorption isotherms enable to know the amount of balance water of a compound exposed to a temperature and relative moisture known [23], and the relationship between adsorption and porosity of materials [24]. The IUPAC conventions have been proposed six types of isotherms, shown in Fig. 1. Type I isotherm is typical in microporous materials, type II, III and VI isotherms are in nonporous or macroporous materials; and IV and V type isotherms in mesoporous adsorbents [24].

Prior to testing, the samples were pre-dried. The silica gel samples were dried at $110^{\circ} \mathrm{C}$ in an oven for $20 \mathrm{~h}$ and the zeolite was kept under vacuum at $200^{\circ} \mathrm{C}$, for the same time. Quantachrome FloVac Degasser was used for the vacuum treatment.

The adsorption-desorption water isotherms at $25^{\circ} \mathrm{C}$ were obtained with the Quantachrome Hydrosorb Model HS-10. The relative moisture inside the machine was increased from 5\% to $95 \%$ in intervals of $10 \%$. The criteria selected to increase the moisture was that the pressure did not vary more than $0.05 \mathrm{mmHg}$ for one minute, being $10 \mathrm{~min}$ the equilibration time chosen. Thus, it ensures that the samples acquire a constant weight for this relative moisture. To calculate the desorption isotherm, the same approach was applied but gradually decreasing the relative moisture. 


\subsubsection{Compactability}

The ease of compaction of different asphalt mixtures was studied using a gyratory compactor. This ease was measured using the Mix Stability Index (MSI). This index is based on the $\%$ air voids-number of cycles curve and on the use of variable limits depending on the aggregate gradation selected. These limits are related to the $\%$ air voids obtained with the Marshall test, the method used in Spain to obtain the optimum binder content $[25,26]$. MSI was calculated as the area from cycle 8 until achieving $98 \%$ of the Marshall density [26]. The compaction parameters applied were: an internal slight angle of $0.82^{\circ}$; a speed of $30 \mathrm{rpm}$; a vertical pressure of $600 \mathrm{kPa}$ [27] and 200 cycles [28].

\subsubsection{Water sensitivity}

The binder-aggregate adhesion was carried out through the water sensitivity test [29]. Six cylindrical specimens (diameter $101.6 \mathrm{~mm}$ and height $63.5 \mathrm{~mm}$ ) were manufactured for each combination of variables studied, separating them into two groups with similar densities: one in dry conditions (air chamber at $20^{\circ} \mathrm{C}$ ) and the other in wet conditions (submerged in water at $40^{\circ} \mathrm{C}$ ) after a vacuum treatment. All the specimens were tested for indirect tensile strength [30], calculating the Indirect Tensile Strength Ratio (\% ITSR) through the strength results of wet $\left(\right.$ ITS $\left._{\mathrm{W}}\right)$ and dry $\left(\right.$ ITS $\left._{\mathrm{D}}\right)$ specimens.

\subsubsection{Stiffness modulus}

The stiffness modulus was calculated according to the European Standard UNE EN 1269726 [31], annex C, using the Indiret Tensile test. A vertical compression load was applied, measuring the horizontal deformation of the cylindrical sample. Each test consists of 16 load cycles of $3 \mathrm{~s}$, using the values from cycle 11 to 15 for the calculation of the stiffness moduli, as the first cycles are necessary for sample settling. The test temperature was $20^{\circ} \mathrm{C}$. 


\subsubsection{Resistance to permanent deformation}

The wheel tracking test was used to analyze the permanent deformation of the asphalt mixtures manufactured and compacted at three different temperatures. Two specimens were manufactured for each combination of variables. For an AC16 gradation, the specimens had the dimensions of $260 \mathrm{~mm} \times 410 \mathrm{~mm}$ x $60 \mathrm{~mm}$ according to UNE EN 12697-22 [32], and they were compacted by a steel segmented roller compactor [33].

The test temperature was $60^{\circ} \mathrm{C}$ [25] and the test is set to endure either 10,000 loading cycles or until the rut depth is $20 \mathrm{~mm}$ [32].

The permanent deformation is measured through mean wheel tracking slope calculated by the following equation:

$$
W T S_{\text {air }}=\frac{\left(d_{10,000}-d_{5,000}\right)}{5}
$$

where:

$$
\begin{aligned}
& \text { WTS }_{\text {air: }} \text { wheel tracking slope for } 1,000 \text { loading cycles }(\mathrm{mm}) \\
& \mathrm{d}_{5,000} \text { : rut depth after } 5,000 \text { loading cycles }(\mathrm{mm}) \\
& \mathrm{d}_{10,000} \text { : rut depth after } 10,000 \text { loading cycles }(\mathrm{mm})
\end{aligned}
$$

\subsubsection{Resistance to fatigue}

The fatigue test is used to evaluate the structural behavior of asphalt mixtures. It measures the distress of the asphalt mixtures showed in cracking form, produced by the accumulation of high number of loads [34].

There are many procedures for the fatigue test depending on the geometry of the specimens [35]. In this research, the four-point bending test was used. The AC16 specimens had a width of $63 \mathrm{~mm}$, a length of $410 \mathrm{~mm}$ and a thickness of $50 \mathrm{~mm}$ according to European 
standard UNE EN 12697-24 [35]. The test temperature was $20^{\circ} \mathrm{C}$ and a sinusoidal waveform at a frequency of $10 \mathrm{~Hz}$ was applied in strain control mode. The failure criteria selected is defined as the loading cycle when a reduction of $50 \%$ of the initial stiffness modulus is produced.

The fatigue model for parallelepiped specimens tested in the four-point bending test, has the following expression:

$$
N=k_{1} \varepsilon^{k_{2}}
$$

Where:

$$
\begin{aligned}
& \mathrm{N} \text { : number of strain applications to failure } \\
& \varepsilon \text { : initial tensile strain in the cycle } 100 \text {, in } \mu \mathrm{m} / \mathrm{m} \\
& \mathrm{k}_{1}, \mathrm{k}_{2} \text { : fatigue growth rate coefficients }
\end{aligned}
$$

\section{Results and discussion}

\subsection{Adsorption isotherms of zeolite and silica gels.}

The adsorption-desorption water isotherms at $25^{\circ} \mathrm{C}$ are shown in Fig. 2. The results indicate that the additives used have different adsorption methods.

The zeolite (F1) showed a type I hybrid isotherm, which indicated that F1 is a microporous compound and the adsorption is produced at lower pressures and with a monolayer mechanism [36]; also showing a hysteresis loop at medium-high pressures, similar to isotherm type IV, due to the presence of mesopores, resulting in capillary condensation in the adsorbent $[37,38]$. Thus, F1 has micropores and mesopores.

In the case of silica gels, F2, F3 and F5 presented a type V isotherm, typical in porous compounds with a weak interaction between the adsorbate and the adsorbent, where the adsorption has a multilayer mechanism [36]. In turn, F4 showed a type IV isotherm, typical 
of mesoporous solids, whose filling process is in multilayer formation. The difference in the hysteresis loops between silica gels may be due to the shape of the pores, their structures and also the gas used in the test [39].

\subsection{Compactability}

According to the results shown in Fig. 3, the use of silica gels improved the compactability of asphalt mixtures, probably due to the reduction of binder viscosity. The difference in the compactability of silica gels may be due to their different internal structure, the intermolecular forces generate between adsorbent and adsorbate (whether it is in monolayer or multilayer formations), temperature at which all water content is released, and /or time to release the water content during the manufacture of asphalt mixtures.

Additives F1, F3, F4 and F5 needed lower compaction energies, between $25-55 \%$, to achieve $98 \%$ of Marshall density at the three temperatures studied than reference mixture at $160^{\circ} \mathrm{C}$ (Rmix). The MSI value of additive $\mathrm{F} 2$ at $120^{\circ} \mathrm{C}$ was lower compared to Rmix, being more easily compactable at this temperature.

So, the use of silica gels may reduce the energy consumption of asphalt mixtures due to the lower manufacturing temperatures used, and the number of cycles of the vibratory roller for their layout.

\subsection{Analysis of mechanical properties}

The water sensitivity test results are shown in Fig. 4. A decrease of \% ITSR values has been obtained reducing the working temperatures, due to the increase in air void content.

Adding additives improved the water sensitivity compared to Rmix at the same temperature, although none of them achieved the minimum values of \% ITSR indicated in the Spanish standard (>80\%) in asphalt mixtures manufactured at $140^{\circ} \mathrm{C}$ and $120^{\circ} \mathrm{C}$. It is remarkable that mixtures with additives manufactured at $140^{\circ} \mathrm{C}$ obtained $\%$ ITSRs close to $80 \%$, and 
modifying the dosage of the asphalt mixture and/or the type of bitumen may be achieves this value.

At $160^{\circ} \mathrm{C}$, wet and dry tensile strength values of majority of asphalt mixtures with additives, were slightly lower than Rmix. However, at $140^{\circ} \mathrm{C}$ and $120^{\circ} \mathrm{C}$, asphalt mixtures with additives showed greater tensile strength than Rmix, in both dry and wet specimens. These greater resistances may be due to the lower percentage of air voids obtained in modified asphalt mixtures, because all additives used in this research did not melt at the manufacturing temperatures used, behaving them as filler.

In Fig. 5, the average of stiffness modulus of four specimens tested for each temperatureadditive combination is shown. Reducing the manufacture temperature, the stiffness moduli decreased in all asphalt mixtures tested because of the increase in air void content. A decrease of $40^{\circ} \mathrm{C}$ in the manufacture and compaction temperatures decreased the moduli of asphalt mixtures with additives between 10-35\% depending on the additive used, but in Rmix this reduction was around $50 \%$.

The results of rutting performance tested at $60^{\circ} \mathrm{C}$ are shown in Table 5. In all cases studied, the permanent deformation increased when the manufacturing and compaction temperatures decreased for the same asphalt mixture. This effect is due to the higher percentage of air voids obtained when reducing the work temperatures, causing a lower rutting resistance. However, comparing the asphalt mixtures at the same manufacture temperature, the percentage of air voids was not the only reason of their rutting behavior, because additivated asphalt mixtures with the same air void content did not obtain the same results. Analysing the rutting results taking into account the characteristics of the additives shown in Table 4, the surface area, particle size or silica content have not shown a clear relationship with the rutting results. Nevertheless, there seems to be a relationship between the pore volume of the different silica gels and the resistance to rutting and, the greater pore volume of additive, the 
greater the WTS results. In the case of F4, whose WTS and RD values always turned out to be the greatest of all the asphalt mixtures evaluated, it may also be due to a specific characteristic of this additive (Table 4): the release of heat by the adsorption of substances, softening the bitumen of the asphalt mixture at the test temperature. All asphalt mixtures with additives showed higher rut depth than Rmix at the same working temperature. Among them, additives F2 and F1 obtained lower permanent deformation than the rest of additives at three manufacturing and compacting temperatures.

The fatigue resistance was analyzed for an HMA and two additives (F1 and F2), which obtained better results in terms of permanent deformation. In this case, the asphalt mixture with additives was manufactured and compacted at $140^{\circ} \mathrm{C}$ (temperature of WMA).

The asphalt mixtures with additives had a higher slope in plots of fatigue tests than HMA (Table 6), which indicates that these asphalt mixtures are more susceptible to change of strain level [40]. Comparing the value obtained at $10^{6}$ cycles, the use of both additives resulted in a lower fatigue life, $7 \%$ in the case of $\mathrm{F} 1$ and $15 \%$ to $\mathrm{F} 2$ compared to HMA.

\section{Conclusions}

In this paper, the use of silica gels has been studied as possible foaming agents for bitumen. Asphalt mixtures manufactured with silica gels showed similar behavior to asphalt mixtures with zeolite, being F2 the silica gel that achieved better performance. The use of silica gels improved the workability of the asphalt mixtures compared to HMA. F3, F4 and F5 obtained lower MSI values (between 25\% and 55\%) to HMA values.

High tensile strength values were obtained for asphalt mixtures with additives compared to Rmix at the same manufacturing and compaction temperature, obtaining an improvement in $\%$ ITSR. Although none of the additivated mixtures manufactured at lower temperatures 
achieved the \%ITSR indicated in the Spanish standard, modifying the dosage of the asphalt mixture and/or the type of bitumen may be achieved it.

Decreasing the manufacture temperature, the asphalt mixtures became less stiff, but with the use of silica gels and zeolite, this reduction of stiffness with temperature was lower than in Rmix. All additives used showed poorer permanent deformation resistance than Rmix at the three temperatures studied. Among them, additives F1 and F2 have better performance. Asphalt mixtures manufactured with $\mathrm{F} 1$ and $\mathrm{F} 2$ at $140^{\circ} \mathrm{C}$ obtained a lower fatigue life, between $7-15 \%$, than HMA.

It is recommended to carry out a research varying the binder penetration and the type of aggregate, as well as the possible use of recycled materials (e.g. RAP) to improve the results and evaluate if it is possible to fulfill the standard requirements. It is also recommended to carry out a research to know the water release temperature of each silica gel studied as well as the time required to release all water adsorbed in silica gels during the manufacture of asphalt mixtures.

\section{Acknowledgments}

The research presented herein was sponsored by the Research Office of Universidad de La Frontera (DIUFRO) under the project number DI15-0089.

\section{Conflicts of Interest}

The authors declare no conflict of interest.

\section{References}

[1] Sanchez-Alonso E, Castro-Fresno D, Vega-Zamanillo A, Rodriguez-Hernandez J. (2011). Sustainable asphalt mixes: use of additives and recycled materials. Balt J Road Bridge E 6 (4): 249-257. 1. DOI: 10.3846/bjrbe.2011.32 
[2] Rodríguez Maldonado JA (2004) [on line]. Hidrogenólisis e hidrotratamiento de residuos de vacío de petróleo tipo maya. PhD Thesis. Departamento de Ingeniería Química y Alimentos, Escuela de Ingeniería. Universidad de las Américas Puebla (México). http://catarina.udlap.mx/u_dl_a/tales/documentos/leip/rodriguez_m_ja/capitulo4.pdf [accessed: April 2012].

[3] Button JW, Estakhri C, Wimsatt A. (2007). A synthesis of Warm-Mix Asphalt. Texas Department of Transportation and the Federal Highway Administration. Report $\mathrm{N}^{\circ}$ FHWA/TX 07/0-5597-1.

[4] Hurley GC, Prowell BD. (2005). Evaluation of Aspha-Min ${ }^{\circledR}$ for the use in warm mix asphalt. National Center for Asphalt Technology (NCAT). Report 05-04.

[5] Akisetty CK, Lee S-J, Amirkhanian SN. (2009). Effects of compaction temperature on volumetric properties of rubberized mixes containing warm-mix additives. J Mater Civil Eng 21(8): 409-415. DOI: 10.1061/(ASCE)0899-1561(2009)21:8(409)

[6] Tao M, Mallick RB. (2009). Effects of warm-mix asphalt additives on workability and mechanical properties of reclaimed asphalt pavement material. Transportation Res Rec 2126: 151-160. https://doi.org/10.3141/2126-18

[7] Sengoz B, Topal A, Gorkem, C. (2013). Evaluation of natural zeolite as warm mix asphalt additive and its comparison with other warm mix additives. Construction and Building Materials 43: 242-252. https://doi.org/10.1016/j.conbuildmat.2013.02.026

[8] Xu S, Xiao F, Amirkhaniana S, Singh D. (2017). Moisture characteristics of mixtures with warm mix asphalt technologies - A review. Construction and Building Materials 142: 148-161. https://doi.org/10.1016/j.conbuildmat.2017.03.069

[9] De Visscher J, Vervaecke F, Vanekstraete A, Soenen H, Tanghe T, Redelius P. (2010). Asphalt production at reduced temperatures using zeolites and the impact on asphalt 
performance. Road Materials and Pavement Design 11 (1): 65-81. https://doi.org/10.1080/14680629.2010.9690260

[10] Woszuk A, Franus W. (2016). Properties of the warm mix asphalt involving clinoptilolite and Na-P1 zeolite additives. Construction and Building Materials 114: 556-563. https://doi.org/10.1016/j.conbuildmat.2016.03.188

[11] Hossain Z, Zaman M, O’Rear EA, Chen D-H. Effectiveness of Advera ${ }^{\circledR}$ in warm mix asphalt. Proceedings of the GeoHunan International Conference - Emerging Technologies for Material, Design, Rehabilitation, and Inspection of Roadway Pavements; 2011 June 9-11; Hunan, China. Geotechnical Special Publication 218: 9-16.

[12] Topal A, Sengoz B, Kok BV, Yilmah M, Agazadeh Dokhandari P, Oner J, Kaya, D. (2014). Evaluation of mixture characteristics of warm mix asphalt involving natural and synthetic zeolite additives. Construction and Building Materials 57: 38-44. https://doi.org/10.1016/j.conbuildmat.2014.01.093

[13] Wu S, Li X. (2017). Evaluation of effect of curing time on mixture performance of Advera warm mix asphalt. Construction and Building Materials 145: 62-67. https://doi.org/10.1016/j.conbuildmat.2017.03.240

[14] Goh SW, You Z. (2011) Evaluation of warm mix asphalt produced at various temperatures through dynamic modulus testing and four point beam fatigue testing. Proceedings of the GeoHunan International Conference - Pavements and Materials: Recent Advances in Design, Testing, and Construction; 2011 June 9-11; Hunan, China. Geotechnical Special Publication 212: 123-130.

[15] Sáenz MC, Báez Quintero CA, Díaz Velásquez JJ, Rodríguez Niño G. (2007). Estudio de las variables de reacción en la síntesis de silica gel adsorbente [Reaction parameter 
study for the chemical synthesis of adsorbent silica gel]. Ingeniería e Investigación. 27 (2): 44-50. ISSN: 0120-5609.

[16] Peña J, Cardona E, Rios L. (2008). Synthesis of silicon oxide with high superficial area and porosity through sol-gel technique using glycerol and glyceryl monostearate as templates [Síntesis de óxidos de silicio de altas área superficial y porosidad empleando el metodo sol-gel en presencia de glicerol y monoestearato de glicerilo como estructurantes]. Dyna 75 (156): 207-216. ISSN: 0012-7353.

[17] Goedecke R. (2011). Fluidverfahrenstechnik. Grundlagen, methodik, technik, praxis. Ed.Wiley-VCH, Weinheim.

[18] Fortier L, Côté S, St-Laurent H, Bernier S, Couture A. (2001). Process for the regeneration of used silica gel. Sylicicle Inc. (Quebec, CA). US Patent: US 6248683B1. Date of patent: 06/19/2001

[19] Chemicalbook Inc. (2017). Silica gel basic information. CAS number: 112926-00-8. IOP Publishing ChemicalBook web. https://www.chemicalbook.com/ProductChemicalPropertiesCB1199389_EN.htm. Accessed 29 April 2018.

[20] UNE EN 12697-30 (2013). Bituminous mixtures. Test methods for hot mix asphalt, part 30: specimen preparation by impact compactor.

[21] UNE EN 12697-8 (2003). Bituminous mixtures. Test methods for hot mix asphalt, part 8: determination of void characteristics of bituminous specimens.

[22] Riberiro FE. (2012). Zeolite and water slurries for asphalt concrete pavement. US Patent: US 2012/0180702A1. Date of patent: 07/19/2012 
[23] Gálvez AV, Aravena EL, Mondaca RL. (2006). Isotermas de adsorción en harina de maíz (Zea mays L.). Food Science and Technology 26 (4): 821-827. http://dx.doi.org/10.1590/S0101-20612006000400017

[24] ALOthman ZA. (2012). A Review: Fundamental Aspects of Silicate Mesoporous Materials. Materials 5: 2874-2902. doi:10.3390/ma5122874

[25] Coleccion normativa tecnica. (2015). Pliego de prescripciones tecnicas generales para obras de carreteras y puentes (PG-3). Articulo 542: Mezclas bituminosas en caliente tipo hormigon bituminoso. Ministerio de Fomento. Espana, 2015.

[26] DelRio-Prat M, Vega-Zamanillo A, Castro-Fresno D, Calzada-Perez MA. (2010). Energy consumption during compaction with a Gyratory Intensive Compactor Tester. Estimation models. Constr Build Mater 25 (2): 979-986. DOI: 10.1016/j.conbuildmat.2010.06.083

[27] UNE EN 12697-31 (2008). Bituminous mixtures. Test methods for hot mix asphalt, part 31: specimen preparation by gyratory compactor.

[28] UNE EN 12697-10:2003 (2003). Bituminous mixtures. Test methods for hot mix asphalt, part 10: compactability.

[29] UNE EN 12697-12 (2009). Bituminous mixtures. Test methods for hot mix asphalt, part 12: determination of the moisture sensitivity of bituminous specimens.

[30] UNE EN 12697-23 (2004). Bituminous mixtures. Test methods for hot mix asphalt, part 23: determination of the indirect tensile strength of bituminous specimens.

[31] UNE EN 12697-26 (2012). Bituminous mixtures. Test methods for hot mix asphalt, part 26: stiffness. 
[32] UNE EN 12697-22 (2008). Bituminous mixture: test methods for hot mix asphalts, part 22: Wheel tracking.

[33] UNE EN 12697-33 (2007). Bituminous mixture: test methods for hot mix asphalts, part 33: specimen prepared by roller compactor.

[34] Moghaddam TB, Karim MR, Abdelaziz M. (2011). A review on fatigue and rutting performance of asphalt mixes. Scientific Research and Essays 6 (4): 670-682. DOI: 10.5897/SRE10.946

[35] UNE EN 12697-24 (2013). Bituminous mixture: test methods for hot mix asphalts, part 24: Resistance to fatigue

[36] García Martínez J [on line]. (2003). Adsorción e intercambio iónico en zeolitas. In: Materiales zeolíticos: síntesis, propiedades y aplicaciones, García Martínez, J.; Pérez Pariente, J., Eds.; Universidad de Alicante: Colección Textos Docentes, 2003, ISBN 978-84-7908-722-7. https://publicaciones.ua.es/va/detall.php?idet=621 [accessed: May 2012].

[37] Flores J, Maubert A, Martín N. (2006). Evaluación de los intercambios iónicos en una zeolita natural Mexicana para la separación de N2-O2 en el aire atmosférico. Revista Mexicana de Ingeniería Química 5 (2): 119-129. ISSN: 1665-2738

[38] Hernández MA, Rojas F, Corona L, Lara VH, Portillo R, Salgado MA, Petranoskii VH. (2005). Evaluación de la porosidad de zeolitas naturales por medio de curvas diferenciales de adsorción. Revista Internacional de Contaminación Ambiental 21 (2): 71-81. ISSN: 01884999

[39] Groen JC, Peffer LAA, Pérez-Ramírez J. (2003). Pore size determination in modified micro- and mesoporous materials. Pitfalls and limitations in gas adsorption data 
analysis. Micropor Mesopor Mat 60: 1-17. https://doi.org/10.1016/S13871811(03)00339-1

[40] Silva HMRD, Oliveira JRM, Peralta J, Zoorob SE. (2010). Optimization of warm mix asphalts using different blends of binders and synthetic paraffin wax contents. Constr Build Mater 24(9), 1621-1631. https://doi.org/10.1016/j.conbuildmat.2010.02.030 


\section{Figure captions}

Fig. 1. IUPAC classification adsorption-desorption isotherms [24].

Fig. 2. Adsorption-desorption water isotherms at $25^{\circ} \mathrm{C}$.

Fig. 3. Evaluation of compactability.

Fig. 4. Tensile strength of different asphalt mixtures.

Fig. 5. Stiffness moduli at $20^{\circ} \mathrm{C}$. 


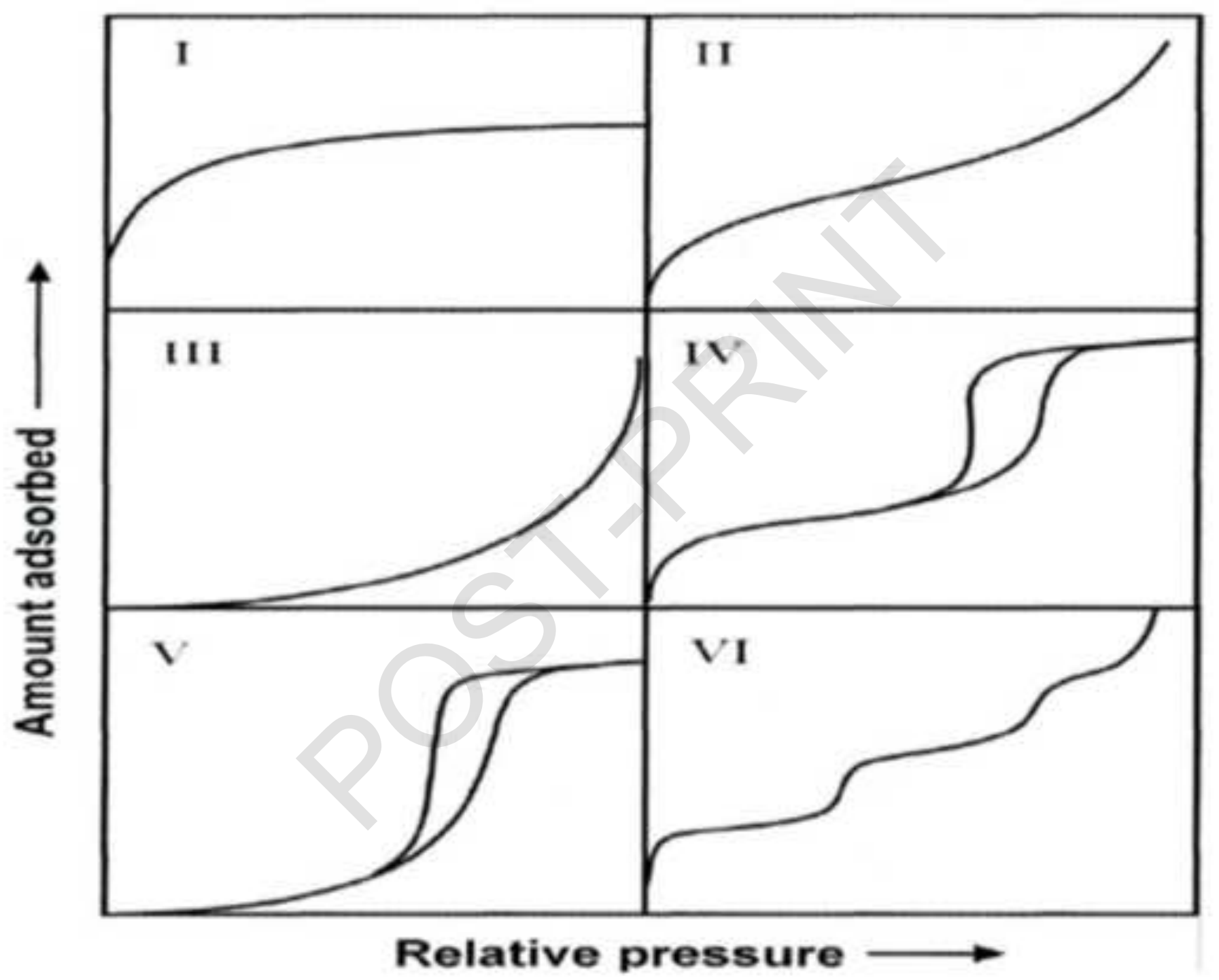

Fig. 1 


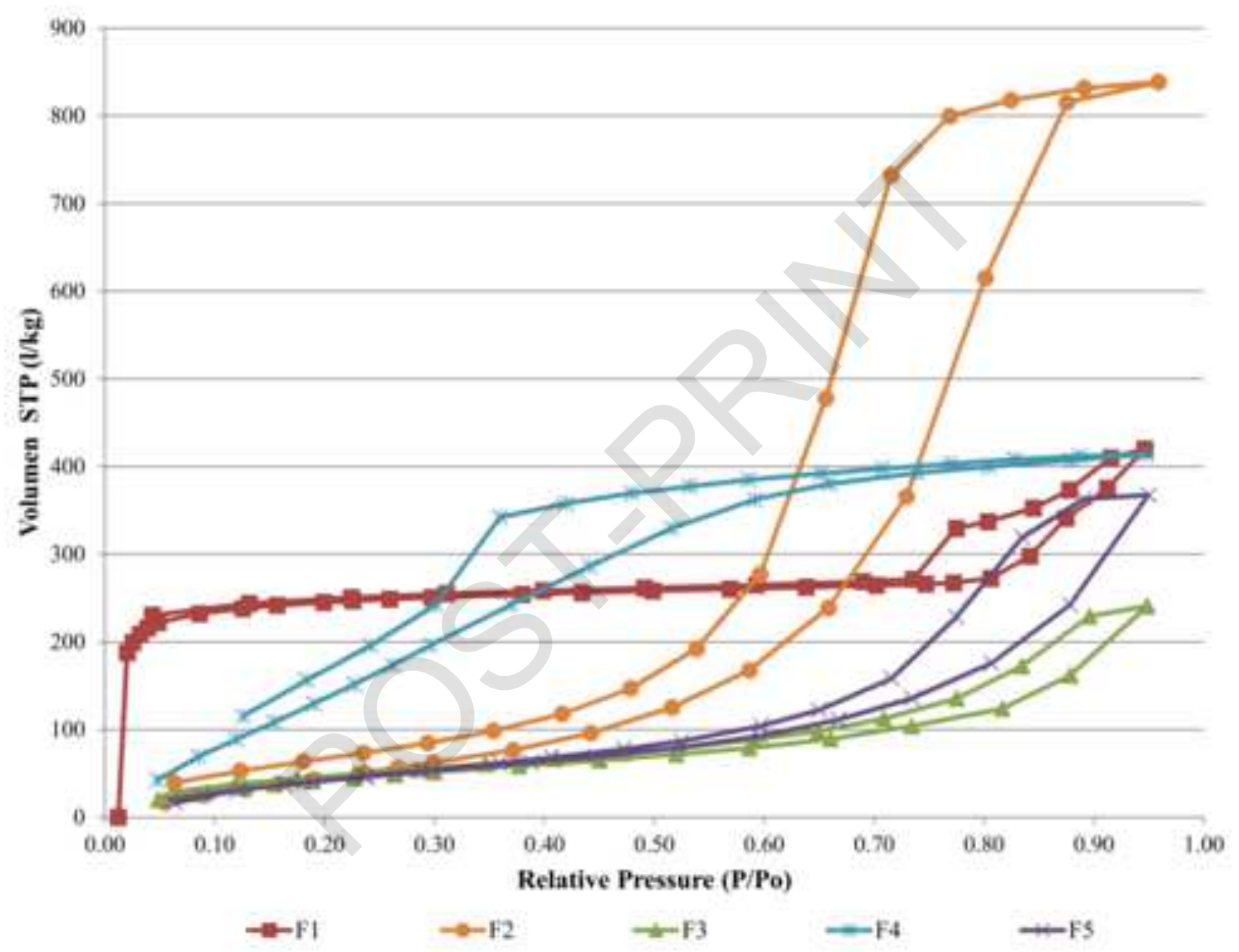

Fig. 2 


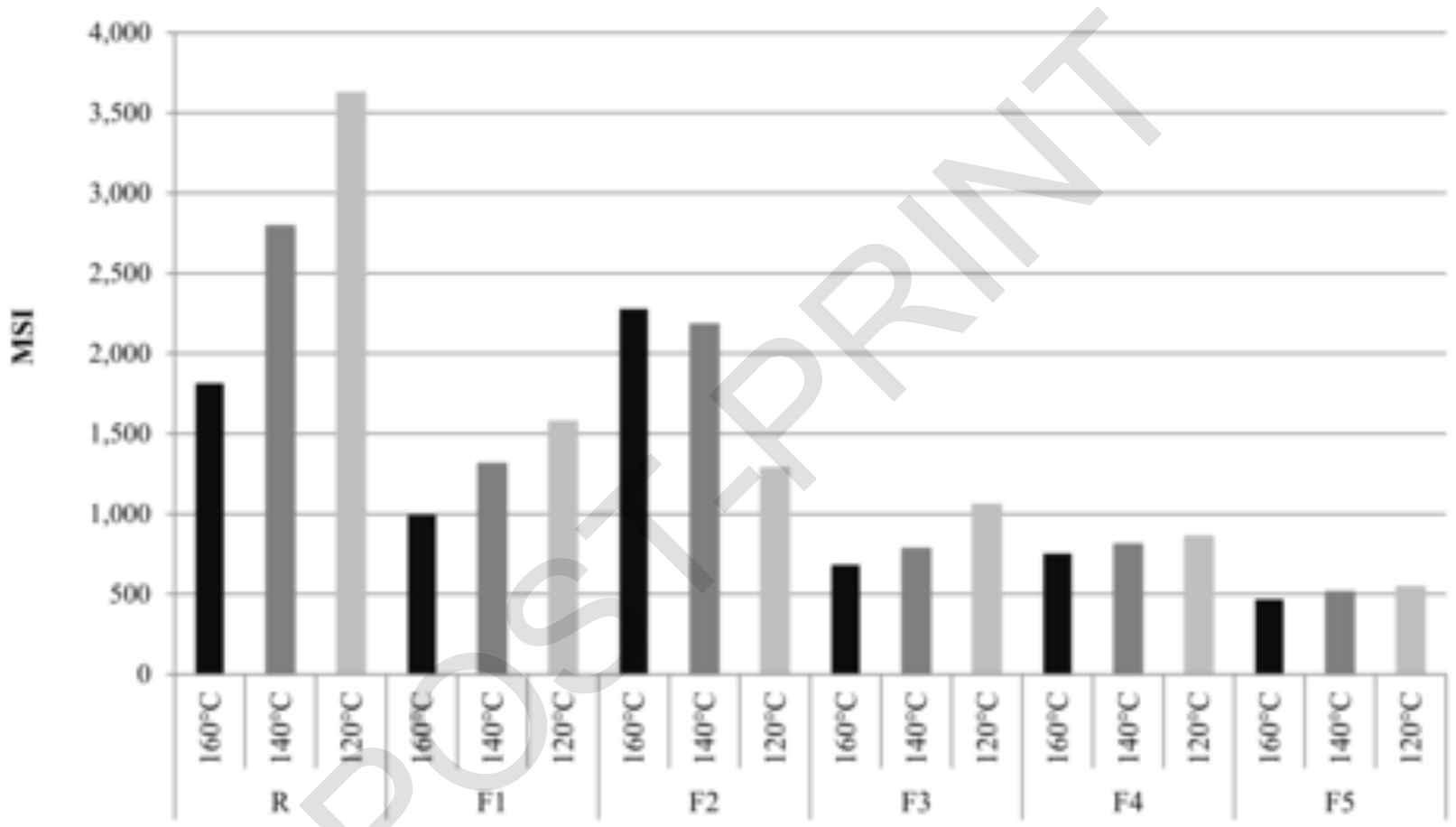

1

3

6

8

9

11

12

14

15

16

18

19

21

22

23

24

26

27

20

30

31

32

33

34

35

36

38

39

40

41

42

43

46

47

48

49 


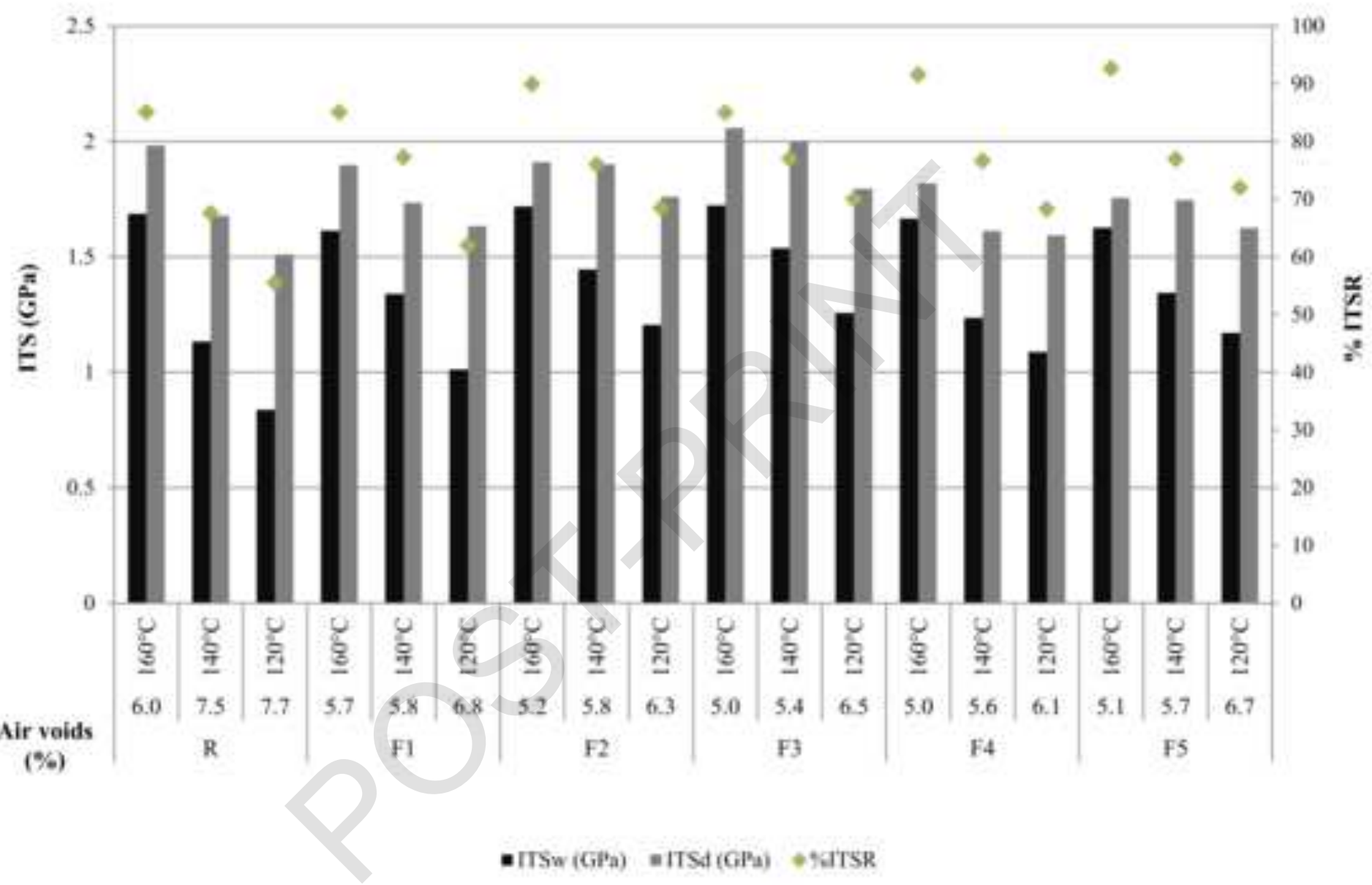

Fig. 4 


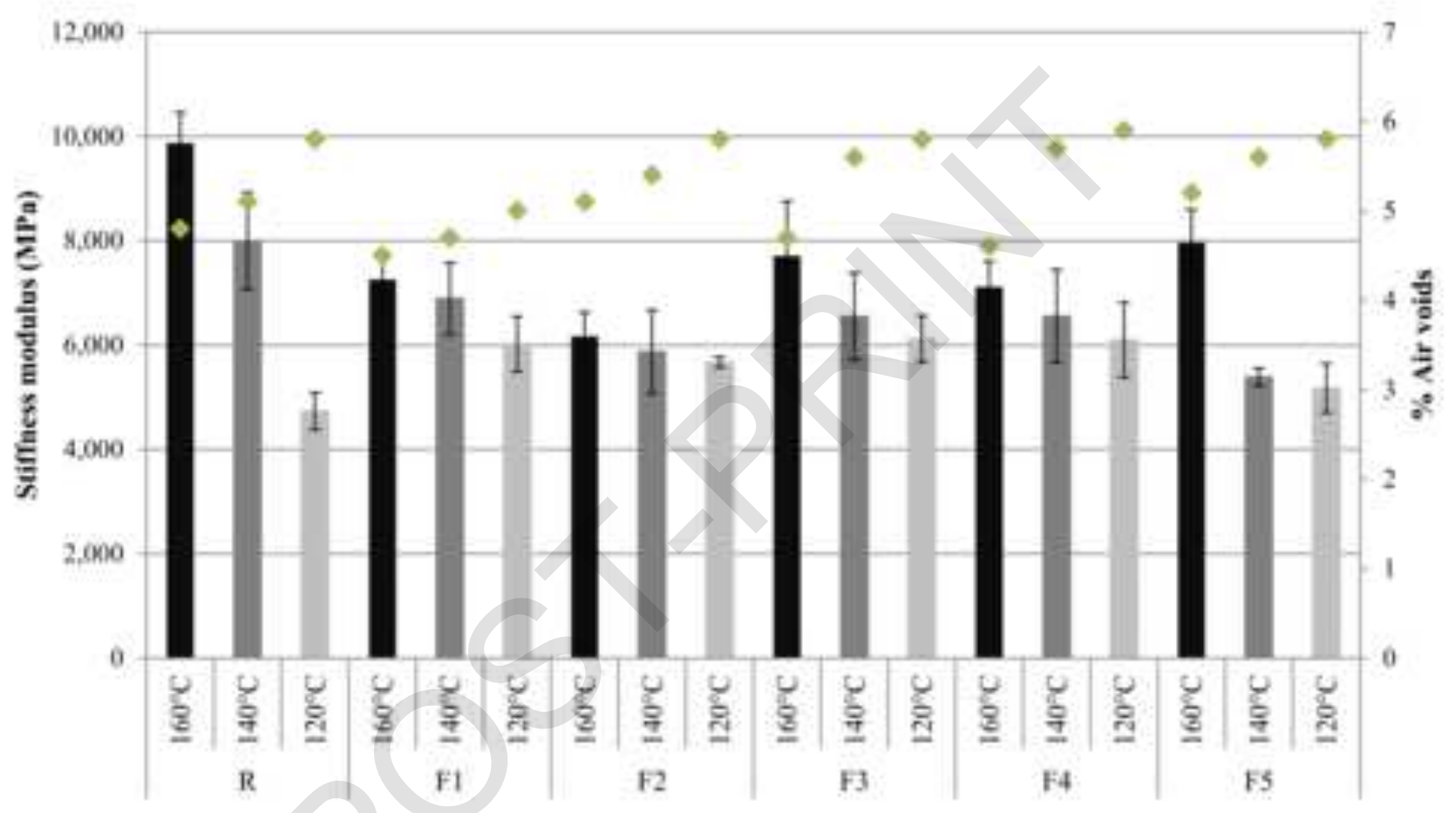

Fig. 5 
Table 1. AC16Surf aggregate gradation.

\begin{tabular}{cccccccccc}
\hline $\begin{array}{c}\text { Particle size, D } \\
(\mathbf{m m})\end{array}$ & $\mathbf{2 2}$ & $\mathbf{1 6}$ & $\mathbf{8}$ & $\mathbf{4}$ & $\mathbf{2}$ & $\mathbf{0 . 5 0 0}$ & $\mathbf{0 . 2 5 0}$ & $\mathbf{0 . 0 6 3}$ \\
\hline & Max. & 100 & 100 & 75 & 50 & 38 & 21 & 15 & 7 \\
$\begin{array}{c}\text { Percent } \\
\text { passing } \\
(\%)\end{array}$ & Min. & 100 & 90 & 60 & 35 & 24 & 11 & 7 & 3 \\
\hline & $\begin{array}{c}\text { Selected } \\
\text { gradation }\end{array}$ & 100 & 95 & 67.5 & 42.5 & 31 & 16 & 11 & 5 \\
\hline
\end{tabular}


Table 2. Aggregate properties.

\begin{tabular}{cccc}
\hline Properties & Standard method & Criteria & Test results \\
\hline $\begin{array}{c}\text { Bulk specific gravity } \\
\left(\mathrm{kg} / \mathrm{m}^{3}\right)\end{array}$ & EN 1097-6 & $\mathrm{n} / \mathrm{a}$ & 2859 \\
LA abrasion (\%) & EN 1097-2 & $<20$ & 13 \\
Flakiness index (\%) & EN 933-3 & $<25$ & 12 \\
Sand equivalent $(\%)$ & EN 933-8 & $>50$ & 60 \\
\hline
\end{tabular}


Table 3. Binder - physical properties.

\begin{tabular}{cccc}
\hline Test & Standard method & Criteria & Test results \\
\hline $\begin{array}{c}\text { Penetration }(\mathrm{dmm}) \\
\text { Specific gravity at } \\
25^{\circ} \mathrm{C}\left(\mathrm{kg} / \mathrm{m}^{3}\right)\end{array}$ & EN 1426 & $50-70$ & 55 \\
Euctility at $25^{\circ} \mathrm{C}(\mathrm{cm})$ & EN 13589 & $>1.0$ & 1031 \\
$\begin{array}{c}\text { Softening point }\left({ }^{\circ} \mathrm{C}\right) \\
\text { Fraas breaking point } \\
\left({ }^{\circ} \mathrm{C}\right)\end{array}$ & EN 1427 & $>90$ & $>90$ \\
Flash point $\left({ }^{\circ} \mathrm{C}\right)$ & ISO 12593 & $46-54$ & $>48$ \\
Penetration of residue, \\
$\%$ of original
\end{tabular}


Table 4. Additives used in this research.

\begin{tabular}{|c|c|c|c|c|c|c|c|}
\hline Terminology & Chemical composition & $\begin{array}{l}\text { State of } \\
\text { additive }\end{array}$ & Regular use & Characteristics & $\begin{array}{c}\text { Particle } \\
\text { size }(\mu \mathrm{m})\end{array}$ & $\begin{array}{c}\text { Pore } \\
\text { volume } \\
\text { (cc/g) }\end{array}$ & $\begin{array}{c}\text { Surface } \\
\text { area }\left(\mathrm{m}^{2} / \mathrm{g}\right)\end{array}$ \\
\hline $\mathrm{F} 1$ & $\begin{array}{l}\text { Synthetic zeolite }(21 \% \text { in mass of } \\
\text { water), sodium aluminosilicate } \\
\qquad\left[\mathrm{Na}_{2} \mathrm{O}: \chi \mathrm{SiO}_{2}: \mathrm{Al}_{2} \mathrm{O}_{3}: \gamma \mathrm{H}_{2} \mathrm{O}\right]^{*}\end{array}$ & Powder form & WMA & $\begin{array}{l}\text { Improve the } \\
\text { manageability of the } \\
\text { mix and the laying } \\
\text { process }\end{array}$ & 350 & 0.18 & 3.1 \\
\hline $\mathrm{F} 2$ & $\begin{array}{l}\text { Synthetic amorphous silica } \\
\qquad\left[99.95 \% \mathrm{SiO}_{2}\right]\end{array}$ & Powder form & Chromatography & $\begin{array}{l}\text { Separation of } \\
\text { compounds by } \\
\text { molecular size. }\end{array}$ & 63 & 0.727 & 496 \\
\hline $\mathrm{F} 3$ & $\begin{array}{l}\text { Synthetic amorphous silica } \\
\qquad\left[98 \% \mathrm{SiO}_{2}\right]\end{array}$ & $\begin{array}{l}\text { Flowing } \\
\text { powder }\end{array}$ & $\begin{array}{l}\text { Anti-caking and } \\
\text { industrial applications }\end{array}$ & $\begin{array}{l}\text { High surface area and } \\
\text { absorption capacity }\end{array}$ & 16 & 1.2 & 190 \\
\hline F4 & $\begin{array}{l}\text { Synthetic amorphous silica } \\
\qquad\left[95-100 \% \mathrm{SiO}_{2}\right]\end{array}$ & Granular & $\begin{array}{l}\text { Refrigerant drying solid } \\
\text { cores, in desiccators and } \\
\text { as desiccant in insulating } \\
\text { glass units }\end{array}$ & $\begin{array}{l}\text { High water capacity. In } \\
\text { active conditions, it will } \\
\text { release heat when } \\
\text { adsorbing water or other } \\
\text { substances. }\end{array}$ & 30 & 2.1 & 500 \\
\hline F5 & $\begin{array}{l}\text { Synthetic amorphous silica } \\
\qquad\left[99.4 \% \mathrm{SiO}_{2}\right]\end{array}$ & $\begin{array}{l}\text { Flowing } \\
\text { Powder }\end{array}$ & $\begin{array}{l}\text { Matting agent in thin film } \\
\text { coating systems and free } \\
\text { flow additive }\end{array}$ & $\begin{array}{l}\text { High porosity, fine } \\
\text { particle size and high } \\
\text { affinity for moisture }\end{array}$ & 6.5 & 1.5 & 300 \\
\hline
\end{tabular}

* General formula for zeolites. $\chi$ and $\gamma$ values depend on the structure type of zeolite [22] 
Table 5. Resistance to rutting at $60^{\circ} \mathrm{C}$ of AC16Surf B-50/70.

\begin{tabular}{|c|c|c|c|c|c|c|c|c|c|}
\hline \multirow{3}{*}{ Mix } & \multicolumn{9}{|c|}{ Manufacturing Temperature } \\
\hline & \multicolumn{3}{|c|}{$160{ }^{\circ} \mathrm{C}$} & \multicolumn{3}{|c|}{$140^{\circ} \mathrm{C}$} & \multicolumn{3}{|c|}{$120^{\circ} \mathrm{C}$} \\
\hline & $\begin{array}{l}\text { WTS }_{\text {air }} \\
\left(\mathbf{m m} / \mathbf{1 0}^{3}\right. \\
{\text { cycles })^{*}}^{*}\end{array}$ & $\begin{array}{l}\text { RD }_{\text {air }} \\
(\mathbf{m m})^{* *}\end{array}$ & $\begin{array}{c}\text { Air } \\
\text { voids } \\
(\%)\end{array}$ & $\begin{array}{c}\text { WTS }_{\text {air }} \\
\left(\mathrm{mm} / \mathbf{1 0}^{3}\right. \\
\text { cycles })\end{array}$ & $\begin{array}{l}\mathbf{R D}_{\text {air }} \\
(\mathbf{m m})^{* * *}\end{array}$ & $\begin{array}{c}\text { Air } \\
\text { voids } \\
(\%)\end{array}$ & $\begin{array}{c}\text { WTS }_{\text {air }} \\
\text { (mm/10 } \\
\text { cycles) }\end{array}$ & $\begin{array}{c}\text { RD air } \\
(\mathbf{m m})^{* *}\end{array}$ & $\begin{array}{c}\text { Air } \\
\text { voids } \\
(\%)\end{array}$ \\
\hline $\mathrm{R}$ & 0.06 & 2.72 & 5.0 & 0.10 & 3.47 & 5.6 & 0.14 & 3.61 & 6.3 \\
\hline $\mathrm{F} 1$ & 0.12 & 3.45 & 4.7 & 0.15 & 3.82 & 5.2 & 0.19 & 4.32 & 5.6 \\
\hline $\mathrm{F} 2$ & 0.10 & 3.16 & 4.8 & 0.14 & 3.38 & & 0.16 & 3.97 & 6.2 \\
\hline F3 & 0.15 & 4.23 & 3.9 & 0.17 & 4.48 & 4.3 & 0.21 & 5.61 & 5.1 \\
\hline F4 & 0.16 & 4.37 & 4.1 & 0.20 & 5.84 & 4,3 & 0.30 & 6.71 & 5.2 \\
\hline F5 & 0.15 & 3.90 & 3.8 & 0.17 & 4.82 & 4.4 & 0.21 & 4.98 & 4.7 \\
\hline
\end{tabular}

"WTS air: mean wheel tracking slope; ${ }^{* *} \mathrm{RD}$ air: mean rut depth. 
Table 6. Results of four-point bending fatigue test.

\begin{tabular}{ccccc}
\hline Mix & $\begin{array}{c}\text { Manufacture } \\
\text { Temperature }\left({ }^{\circ} \mathbf{C}\right)\end{array}$ & Fatigue Line & $\mathbf{R}^{2}$ & $\begin{array}{c}\text { Fatigue Resistance, \&6 } \\
(\boldsymbol{\mu m} / \mathbf{m})\end{array}$ \\
\hline $\mathrm{R}$ & 160 & $\mathrm{~N}=10^{22.184}(\varepsilon)^{-6.679}$ & 0.946 & 208.5 \\
$\mathrm{~F} 1$ & 140 & $\mathrm{~N}=10^{20.924}(\varepsilon)^{-6,531}$ & 0.978 & 192.9 \\
$\mathrm{~F} 2$ & 140 & $\mathrm{~N}=10^{17.699}(\varepsilon)^{-5.206}$ & 0.985 & 176.7 \\
\hline
\end{tabular}

